\title{
Language and Dialect Boundaries in Local Content of Regional Language in Tapal Kuda
}

\author{
Agusniar Dian Savitri \\ Universitas Negeri Surabaya \\ Surabaya, Indonesia \\ agusniarsavitri@unesa.ac.id
}

\author{
Dianita Indrawati \\ Universitas Negeri Surabaya \\ Surabaya, Indonesia \\ dianitaindrawati@unesa.ac.id
}

\author{
Suhartono \\ Universitas Negeri Surabaya \\ Surabaya, Indonesia \\ suhartono@unesa.ac.id
}

\begin{abstract}
Local content in Pasuruan, Probolinggo and Lumajang is the Java language, whereas there are areas where people are Madura speaker and bilingual Javanese-Madurese. On the other hand, the definition and purpose of local content is between one region and another region may be different. Based on that, it is necessary to study the language and dialect boundaries in the three districts to know the areas that are the areas of Java and Madura language and dialect. Data collection methods are structured interviews. The method of data analysis is dialectometry. The result of this study is that language and dialect borders are not aligned with district administrative boundaries. There is an intersection between administrative boundaries with language and dialect borders. Thus, it can be concluded that the determination of local content in Pasuruan, Probolinggo and Lumajang districts cannot be based on administrative boundaries only, but needs to consider language and dialect borders. It needs to be done so that the purpose of local content to develop competence in accordance with the characteristics of the region can be achieved..
\end{abstract}

Keywords- language boundaries; dialect boundaries; administrative boundaries; local content of regional language

\section{INTRODUCTION}

Pasuruan, Probolinggo, and Lumajang districts are the regencies in East Java Province with two language speakers, Javanese speakers and Madurese speakers. These two languages are the mother tongue for the speakers. As mother tongue, Javanese and Madurese languages in the three districts are passed from one generation to the next. But there are obstacles in the inheritance. One of the pressures in inheritance of mother tongue is pressure from the school [1]. The pressure is related to the local content imposed at school. Local content in the form of regional languages, has been decided by provincial administrative boundaries, not by language border [1]. It also happened in Pasuruan, Probolinggo and Lumajang districts. The local content used in the three districts is based on administrative boundaries. Thus, local content of regional languages in these three districts is Javanese. In fact, there are areas whose people are Madurese speakers, and there are areas where people are bilingual people of Java-Madura.

In the determination of local content in areas that use more than one language, administrative boundaries are not sufficient to be used as a guide. It takes a picture of language boundaries and dialects that reflect the language speakers' usage. Therefore, the aim of this study is to generate language boundaries and dialect boundaries in the districts of Pasuruan, Probolinggo, and Lumajang so that which areas are the language of Java and its dialect, and Madurese language and its dialect can be identified. These results can be used as guidance in determining local content of regional language in the three districts.

\section{METHOD}

This research is a dialectological research consisting of 19 observation points in three districts. The data collection methods used are structured interview techniques. The number of informants interviewed was 10-15 informants at each observation point. The list of questions used was a list of questionnaires of Badan Bahasa consisting of 1089 vocabulary. Data analysis method used is dialectometry method to know the status of variation in the Tapal Kuda area.

\section{RESULT AND DISCUSSION}

\section{A. Variation, Language and Dialect Boundaries in} Tapal Kuda Areas

The determination of language variation and dialect in this study is based on the calculation of the variation of each observation point. The technique used in the calculation is a dialectometric triangle. 


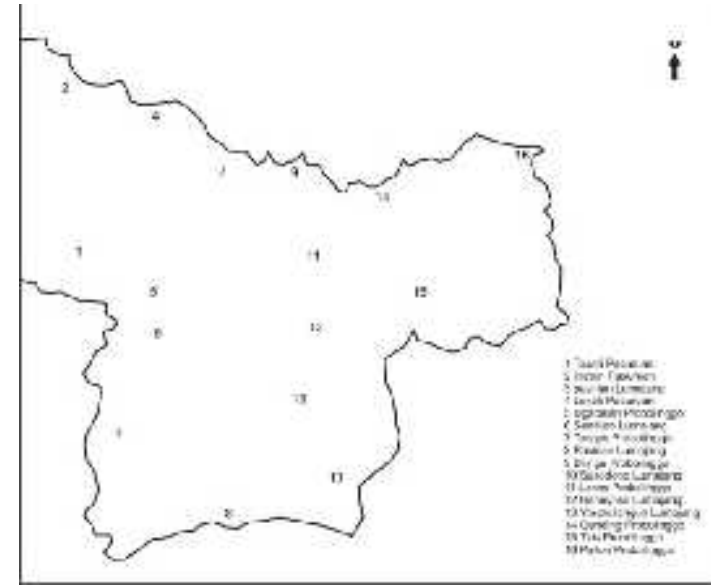

Fig. 1 Basic Map

Fig. 1 above is a basic map of research observation point. The comparison of dialectometric triangles is found in fig. 2 follows.

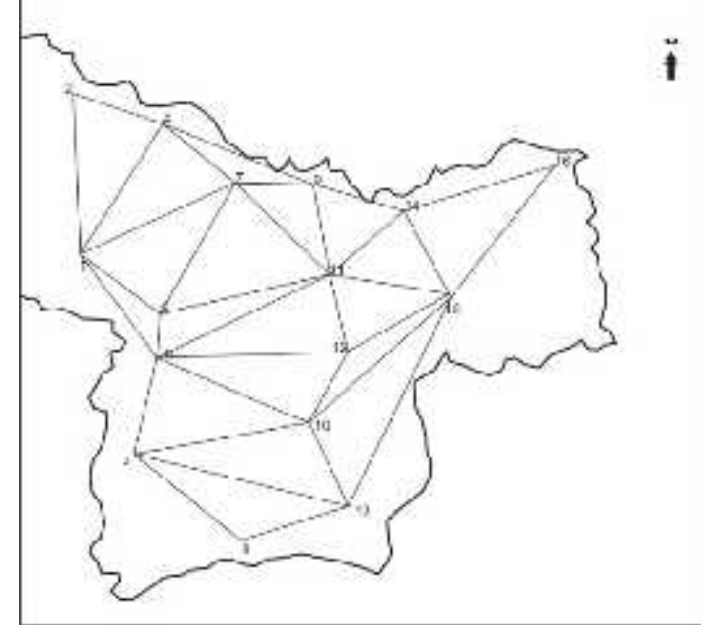

Fig. 2 Map of the dialectometry triangle

Based on the base map in fig.1, a dialectometric triangle is constructed in fig. 2. The observation point (TP) connected by the triangle line is the observed point of comparison. Based on this, the results obtained in the following table.

Table I. Calculations of the Dialectometric Triangle

\begin{tabular}{|l|l|}
\hline Comparison of TP & Status of variation \\
\hline $1-2$ & dialect differences \\
\hline $1-4$ & language differences \\
\hline $1-5$ & subdialect differences \\
\hline $1-6$ & speech differences \\
\hline $1-7$ & language differences \\
\hline $2-4$ & language differences \\
\hline $3-6$ & dialect differences \\
\hline $3-8$ & language differences \\
\hline $3-10$ & speech differences \\
\hline $3-13$ & speech differences \\
\hline $4-7$ & dialect differences \\
\hline $4-9$ & language differences \\
\hline $5-6$ & subdialect differences \\
\hline $5-7$ & language differences \\
\hline $5-11$ & language differences \\
\hline $6-10$ & subdialect differences \\
\hline $6-11$ & language differences \\
\hline $6-12$ & language differences \\
\hline
\end{tabular}

\begin{tabular}{|l|l|}
\hline $7-9$ & language differences \\
\hline $7-11$ & speech differences \\
\hline $8-13$ & language differences \\
\hline $9-11$ & language differences \\
\hline $9-14$ & speech differences \\
\hline $10-12$ & language differences \\
\hline $10-13$ & speech differences \\
\hline $10-15$ & language differences \\
\hline $11-12$ & speech differences \\
\hline $11-14$ & language differences \\
\hline $11-15$ & subdialect differences \\
\hline $12-15$ & subdialect differences \\
\hline $13-15$ & language differences \\
\hline $14-15$ & language differences \\
\hline $14-16$ & language differences \\
\hline $15-16$ & subdialect differences \\
\hline
\end{tabular}

Based on the table, there are four variation states. The languages found in the three districts are Javanese and Madurese, the dialects found are Jawatimuran dialect, Tengger dialect, Madura Barat dialect, and Madura Timur dialect. The status of the variation is illustrated in fig. 3 below.

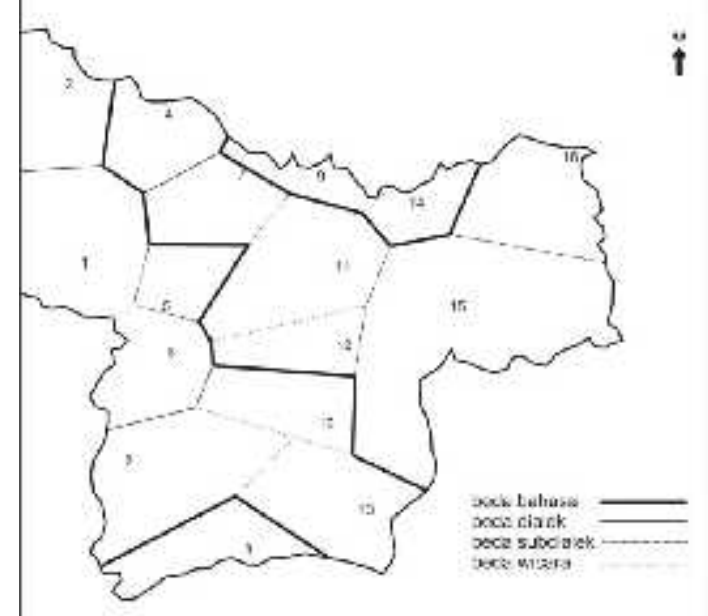

Fig. 3 Map of the Results of Calculation of Dialectometry

Based on the map in fig. 3, it can be seen that there are three boundaries of language-marked with a thick line-in the districts of Pasuruan, Probolinggo, and Lumajang. The first language boundary is the boundary of language that separates the Madurese language from the Javanese language, the thick line separating TP 9 and 14 with TP 4, 7, 11, 15, and 16. TP 9 and 14 are areas of Javanese language with the influence of Madurese, while TP 4, 7, 11, 15, and 16 are areas of Madurese language use. The second language boundary is the language boundary that separates Madurese language with Javanese language (dialect of Tengger and dialect of Jawatimuran). The boundary is marked with a thick line in the middle. The third language boundary is the language boundary that separates the Javanese language with the Madurese language. The boundary is marked by a thick line separating TP 8 (the Madurese language area) with TP 3 and 13. In addition to the language boundary, there is a dialect boundaries, that is Tengger dialect boundary which grouping TP 1,5 , and 6 ; the boundary of the Madura Timur dialect and the Madura Barat dialect separating 
TP 4 by 7; as well as the boundary of the dialect of Jawatimuran that separate TP 1 by 2 ; and TP 6 with 3,10 .

The language and dialect boundaries depicted in fig. 3 show the languages differences and dialects used in the Tapal Kuda areas: Pasuruan, Probolinggo and Lumajang. Based on the map can be seen that Madurese language and its dialect tend to be in the middle. Only two points indicate the Madurese language area on the edge (beach). Seen from the geographical condition, the central area is a mountainous area that is included in the district of Probolinggo, Lumajang, and Jember. In addition to the Madurese language area, there are also Tengger dialect areas not only located in Probolinggo, but also in Pasuruan and Lumajang districts.

The boundary that separates Javanese and Madurese languages in some districts of Pasuruan, Probolinggo and Lumajang shows that there are groupings of languages and dialects in the three districts. The grouping means speakers in the Madurese language area using Madurese language in a day-to-day communication situation, as well as with Javanese speakers in the Javanese language area. The grouping is caused by two things. First, the tendency of Madurese speakers to live in groups with each other. Madurese speakers in the Tapal Kuda area are migrants from Madura Island that have occurred since colonial times. One of the causes of migration at that time was the use of Madurese speakers as laborers in plantations. Therefore, until now Madurese speakers who later produce the Madurese language areas in the Horseshoe tend to be in mountainous areas or plantations. Second, Madurese speakers who live in Madurese enclave tend to maintain their language as a means of daily communication. Geographical conditions that are in the mountains make them rarely interact with other communities, especially the tribal communities of Java. Therefore, Madurese language preservation is still done by Madurese speakers to the next generation. The situation is also reflected in the linguistic situation in the Tapal Kuda area. The bilingual areas of Java-Madura tend to be near government centers or areas that have access to provincial and district roads. However, this bilingual tendency is Madurese speaker who tends to be a Madurese-Javanese bilingual speaker, not the other way around.

\section{B. Language and Dialect Boundaries and Administrative} Boundaries in Determination of Local Content of Regional Language

The language and dialect boundaries depicted in fig. 3 show there is a grouping of languages and dialects in the Tapal Kuda area. Overall, the map in fig. 3 illustrates the linguistic situation who was found in the Tapal Kuda area: in parts of Pasuruan, Probolinggo and Lumajang districts. Then what about the administrative boundaries of the three districts which was found in the Tapal Kuda area? In fact, the administrative boundaries that exist in a district are not always aligned with the language boundaries, especially in districts with two language speakers. Not all regions are bilingual areas, and not all regions have the same linguistic situation. It can be seen on the following two maps.

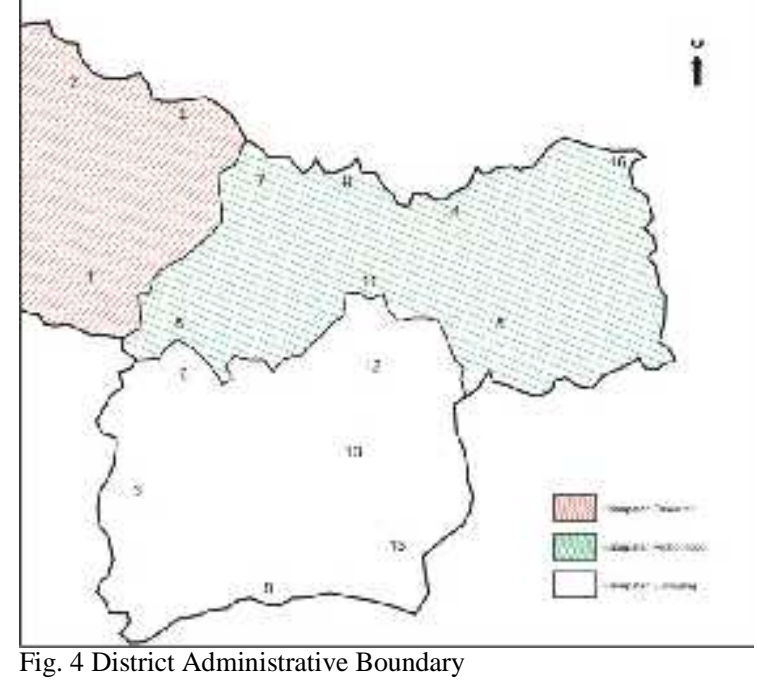

The map on fig.4 is the administrative boundary of Pasuruan, Probolinggo and Lumajang districts. The language and dialect boundaries in the three districts can be seen in the following fig. 5 .

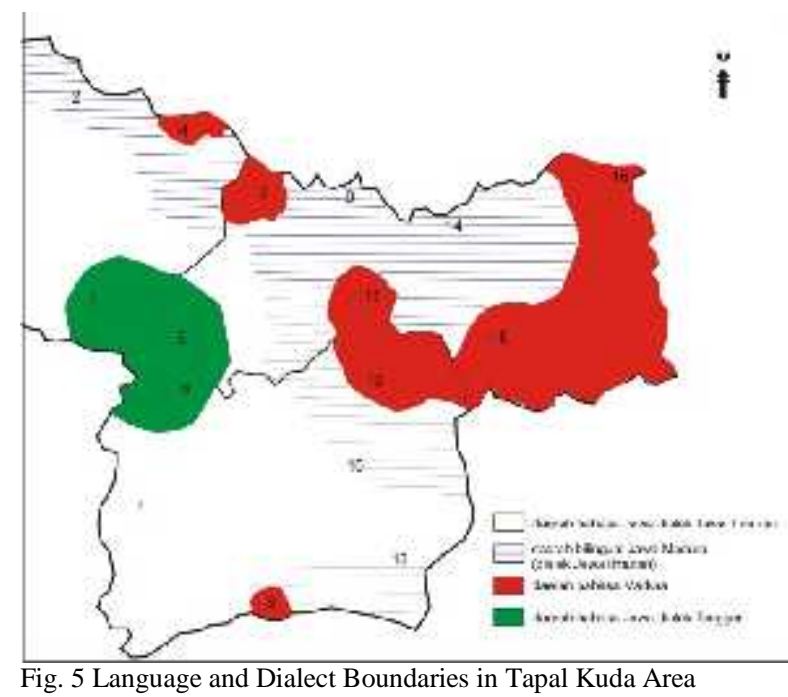

It can be seen in figures 4 and 5, administrative boundaries are not aligned with language and dialect limits. The boundaries of Madurese and Javanese languages crossed the administrative boundaries of the three districts. The same is true of Tengger dialect boundary. Tengger dialect areas include Pasuruan, Probolinggo, and Lumajang districts. That means the Tengger dialect area is beyond of the administrative boundaries of the three districts.

Unconformity between linguistic boundaries with administrative boundaries has also been studied by Auer. In this study, language boundaries are not just beyond administrative boundaries, but also over political boundaries. That is, in different administrative regions but in the same language area, the language speakers feel that they are the same nation as the speakers in different administrative areas. For instance, Dutch citizens residing in the German language 
area feel themselves as German although they are administratively they are in the Netherlands [2]. The same case is also presented in the Tapal Kuda area. Lumajang people who stay in Madurese language area feel themselves are Madurese even though administratively they are in Java.

Based on the two maps, how is it related to local content of regional languages? Local content is a curricular activity that serves to develop competencies tailored to the characteristics and potential of the region, whose material cannot be part of other subjects so it must be a separate subject [3]. The local content is part of the curriculum structure and contentcontained in the Content Standards in the educational unit level curriculum-whose organization is not centralized to be relevant to local circumstances and needs [3]. Local content is a subject, so that the educational unit should develop competencies standards and basic competencies for each type of local content held [3]. Local content aims to 1) introduce learners to their natural, social, and cultural environments; 2) equip the learners to have the skills and knowledge and knowledge about the area that is useful for themselves as well as the society in general; 3) equip learners to have attitudes and behaviors that are in harmony with the values or rules applicable in the region and to preserve and develop the noble values of local culture in order to support the national development [3].

The definition and the aim of local content give the understanding that local content between one region and another can be different. Why is that? In the third purpose, it is said "... has attitudes and behaviors that are in harmony with the values or rules that are in its area ...". In this regard, one way of planting attitudes and behaviors is done through the regional language. In this case, the regional language which is the native language of the speakers. Thus, if in Pasuruan, Probolinggo and Lumajang districts have Javanese and Madurese language areas, the local content in the three districts is Javanese and Madurese.

Based on the notion of local content, language maps has an important function to determine local content of regional languages in the district. In the language map, it is depicted that language boundaries and dialect boundaries which indicate the language and dialect the language speakers use. Therefore, through language maps, local content of regional languages can be determined.

In case of the Tapal Kuda: Pasuruan, Probolinggo, and Lumajang areas, the Madurese language boundary is in three districts, as well as the boundary of Javanese language, and its dialect. In this case, what needs to be distinguished is the Tengger dialect, because the dialects that exist in the northern part of East Java include the dialect of Jawatimuran [4]. In fig. 5 it appears that the Jawatimuran dialect who was found by Kisyani was also found in Lumajang. Thus, the local content of Javanese language in the three districts is the same. It should be distinguished by TP 1,5 , and 6 . Local content in the area should be Tengger dialect. This is necessary because there are many variations between the Tengger dialect and the dialect of the Jawatimuran. In addition, the determination of local content of the Tengger dialect also serves to preserve Tenggerese cultures.

In addition to language boundaries, it appears on the map (fig. 5) that Madurese language is existed in three districts. Thus, local content of regional languages in these three districts are the Javanese and Madurese languages. Javanese language that is used as a local content is dialect Jawatimuran and dialect Tengger. Madurese language that is used as a local content in Probolinggo and Lumajang is Madura Timur dialect, while Madura language which is used as a local content in Pasuruan is Madura barat dialect.

\section{CONCLUSION}

Language and dialect boundaries in the Tapal Kuda: Pasuruan, Probolinggo, and Lumajang areas show different languages and dialects. Based on the result of dialectometry triangle can be seen that Madurese language tend to be in the middle. Only two points indicate the Madurese language area on the edge (beach). In addition to the Madurese language area, there are also Tengger dialect areas which is located in Probolinggo, Pasuruan and Lumajang districts. Thus it can be concluded that administrative boundaries are not aligned with language and dialect boundaries. The boundaries of the Madurese and Javanese languages crossed the administrative boundaries of the three districts, as well as the boundaries of the Tengger dialect. That means, the local content that needs to be applied in Pasuruan Regency that entered the Tapal Kuda area is the Javanese dialect of Jawatimuran and Tengger dialect, as well as the Madura dialect of Madura Barat. Local content that needs to be applied in Probolinggo and Lumajang districts is the Javanese language (Jawatimuran dialect) and Madurese language (Madura Barat dialect).

\section{REFERENCES}

[1] M. R. M. T. Lauder, Sekilas Mengenai Pemetaan Bahasa. Jakarta: Akbar Media Eka Sarana, pp.108-120, 2007.

[2] P. Auer, "The Construction Of Linguistic Borders And The Linguistic Construction Of Borders" in Dialects Across Borders Selected Papers From The 11th International Conference On Methods In Dialectology (Methods XI), vol 273, August 2002.

[3] BNSP. "Lampiran Peraturan Menteri Pendidikan Nasional Nomor 22 Tahun 2006 Tanggal 23 Mei 2006 Standar Isi”. Depdiknas, 2006.

[4] K. Laksono, Bahasa Jawa di Jawa Timur Bagian Utara dan Blambangan: Kajian Dialektologis. Jakarta: Pusat Bahasa Depdiknas, pp. 207-215, 2004 . 